\title{
Four recent books on spirituality and the Psalms: some contextualising, analytical and evaluative remarks ${ }^{1}$
}

C J S Lombaard

(University of South Africa)

\section{ABSTRACT}

In the four years from 2002 to 2005, four new books on the Psalms and spirituality have been published. These are:

- Stuhlmueller, C 2002. The spirituality of the Psalms. Collegeville, Minnesota: Liturgical Press.

- Brueggemann, W 2002. Spirituality of the Psalms. Minneapolis: Fortress Press.

- Waaijman, K 2004. Mystiek in de psalmen. Baarn: Uitgeverij Ten Have.

- Firth, D G 2005. Hear, o Lord. A spirituality of the Psalms. Calver: Cliff College Publishing.

In this paper, brief remarks on the context within which this publication trend takes place, are made. Each of the works is then briefly described, and general evaluative remarks are concluded with.

\section{INTRODUCTION}

The turn to Spirituality in our time, much to the surprise of those who had earlier predicted a religionless future for humanity, still begs adequate sociological explanation. Although some explanations have been offered - such as a reaction to a dehumanising technocratic age - these are of course only partial explanations. Some have ventured to ascribe the growth of interest in Spirituality in Christian circles to an anti-intellectual turn, and though there may be truth to this criticism in some instances, it certainly does not hold true in any universal sense. The blossoming of interest in Biblical Spirituality goes to prove this point: here is a discipline that does not seek less rigorous critical exegetical work and hermeneutical reflection, but asks for more. This "more" is that the usual scholarly exegesis of a biblical text be related, contextually (that is, historically - cf. de

1 Paper presented at the SPIRASA (Spirituality Association of South Africa) congress, 20 January 2006, University of Stellenbosch. 
Villiers 1999:423-425) to its interpreters through the ages (the wirkungsgeschichtliche approach to exegesis), up to and including the lives of the faithful of today (cf. Craghan 1983:2; Bezuidenhout 1995:714-715; Snyman 1997:382-383;). The communio sanctorum thus find themselves, through their relationship in faith, facilitated by any particular text, related to one another - a choir of voices singing not necessarily in harmony, but at least from the same sheet. An ancient oral tradition, becoming a text, edited, placed within literary contexts, canonised, read and applied through the ages by individuals and communities, up to our time - all within concrete socio-historical circumstances - such is the acrobatic tumble of meaning.

This interest in biblical spirituality is demonstrated by a series of four more-or-less unrelated books that have been published from 2002 to 2005 with the title indicating a direct focus on the spirituality of the Psalms. The four publications are:

- $\quad$ Stuhlmueller, C 2002. The spirituality of the Psalms. Collegeville, Minnesota: Liturgical Press.

- $\quad$ Brueggemann, W 2002. Spirituality of the Psalms. Minneapolis: Fortress Press.

- Waaijman, K 2004. Mystiek in de psalmen. Baarn: Uitgeverij Ten Have.

- Firth, D G 2005. Hear, o Lord. A spirituality of the Psalms. Calver: Cliff College Publishing.

Each of these contributions will now be described briefly, with some analytical remarks, upon which follows an interpretative overview.

\section{STUHLMUELLER'S HISTORICAL SPIRITUALITY OF THE PSALMS}

Carrol Stuhlmueller, passionist priest and Old Testament scholar at the Catholic Theological Union in Chicago until his death in 1994, left among his possessions an almost completed manuscript titled The spirituality of the Psalms. The University of Portland Old Testament scholar Carol Dempsey subsequently edited and updated this manuscript, appending to it as closing chapters earlier work by 
the deceased author on Psalms 1 and 2 (Stuhlmueller 1983), and published this work in 2002 under Stuhlmueller's name alone².

The opening pages of this book seeks to place the Psalms within its broader biblical framework; it does so, however, by referring only to some New Testament Psalm quotations (Stuhlmueller 2002:1, 8). In the rest of the book, though, wide-ranging and, more importantly, well-considered references to pertinent texts from both Testaments are added amply (e.g. Stuhlmueller 2002:95101; cf. 38-41) ${ }^{3}$. This broad inner-biblical referencing technique, one senses, serves within the North American context carefully to undermine the fundamentalist knee-jerk reaction to historical readings of the Psalms, namely to make New Testament texts' employment of Psalm references normative for modern exegesis (cf. e.g. Stuhlmueller 2002:18-20; cf. 71ff). The ambience of committed faith within which this is clearly done by the author (Nowell 2003:479; cf. e.g. Stuhlmueller 2002:23-24), renders this book a valuable tool to convey the faith-building value of historical-critical renderings of the Bible texts.

Stuhlmueller's approach is what may be termed existentialromantic: he tries to enter into the life world of the ancient Psalm singers. By noticing the very fine details of everyday life reflected a Psalm, one can "meet, with solicitude and openness, an ancient culture and people" (Stuhlmueller 2002:3; cf. 13, xx). By not in the first instance "evaluating their usefulness or importance", we meet the Psalms/Psalmists “on their own grounds” (Stuhlmueller 2002:3). It is therefore important to take seriously the oral and redactional processes, both ancient (found in the Hebrew, Septuagint and Vulgate texts) and modern (in different translations), behind the Psalm collection as we have it, and the history that influenced such processes (Stuhlmueller 2002:3-8). The Deutero- and Trito-Isaiah texts are frequently, if briefly, indicated as parallels of sorts to ancient redactional work on the Psalm collections.

2 One is left slightly at a loss, here and there, whether to ascribe stylistic variations in the text of this book to the writing technique of Stuhlmueller or to the editing by Dempsey.

3 Are the opening pages thus one instance where one may suspect Dempsey's hand? 
Using Psalm 95 as example, Stuhlmueller (2002:9-24) then illustrates how a passage could be read at once as historical, literary and prayer text. By combining close attention to the text with the reader's imagination ${ }^{4}$, the ancient tradition as it had already been actualised in the text itself, in the church through the centuries, and in the individual's own life, gain a fuller meaning. Without indicating it, Stuhlmueller here ${ }^{5}$ combines tradition-historical exegesis, classically à la von Rad (cf. especially Von Rad 1962), with the more modern reception-historical approach (the latter not in the philosophical hermeneutical sense - cf. Thiselton 1992:80-141 - but in the wirkungsgeschichtliche sense - cf. Grimm 1977), thus creating a chain of meaning to which the reader of the psalm may now be linked. Inner-Testamental and inter-Testamental quotations, allusions and debates, references by the Church Fathers, and the interpretations of leading spiritual lights through the centuries, find acknowledgement alongside modern exegetical scholarship (Stuhlmueller 2002:21-24). In this, Stuhlmueller is fully a child of Vaticanum II (cf. Stuhlmueller 2002:23-24).

Within such a working framework, it is possible, for instance, for Stuhlmueller (2002:25-38, 42-47) to address within fortifying sections on hymns of praise the sensitive historical issue of the polytheistic background to the Old Testament, or to use the $\mathrm{J}$ and $\mathrm{P}$ textual layers of the Exodus account of the first plague to describe how secular history becomes faith history. Thus, grouping the Psalms thematically (i.e. praise; the Lord as King and Creator; the royal Psalms; lament, both communal and individual; illness and death; rejection and resolution; wisdom; and thanksgiving), Stuhlmueller (2002:25-202) not only discusses the range of life experiences reflected in the Psalms, but also relates these to issues and experiences of modern life.

Stuhlmueller thus succeeds in combining a reading of the text of the Psalms which is unequivocally historically oriented with a spiritual life that is indisputably related to God. Context ancient meets context modern in a fulfilling interaction between ancient Scripture and modern reader. To my sensibilities, this is the model

4 See also Stuhlmueller (2002:77-78), where he combines the work of De Vaux (1961) with imagination.

$5 \quad$ More explicitly so in Stuhlmueller (2002:49). 
for interaction with the Scriptures by individuals and the church which holds the greatest promise for a theologically and intellectually sustainable interface.

\section{BRUEGGEMANN'S ANALYSIS OF THE PSALMS}

Since, most particularly, his 1982 Genesis commentary, Walter Brueggemann (Columbia Theological Seminary Old Testament scholar and Presbyterian church leader) has been known for his ability to translate complex technical exegesis into a more popular mode, so as to be accessible to readers not well versed in the necessary scholarly apparatus. Brueggemann has developed a style of academic writing which may be described as "analytical", "conceptual", or "paradigmatic" (not in the academically accepted sense of Kuhn 1970). This entails, with all the necessary introductory exclusions and limitations, the use of certain concepts, often combined opposites, with which to analyse a text or body of texts - an approach again to be seen in his influential recent Theology of the Old Testament (Brueggemann 1997). Though it may leave much about the texts unsaid, this approach has the benefit that new thematic relationships between texts can be laid, in a concise and accessible - "eminently practical", according to Craghan 1983:125 - way (Brueggemann 2002:vii-viii). Certain concepts are employed as analytical frameworks with which to read the texts of the Bible, often with a view to comment on modern social, political and ecclesial concerns. Thus, this style of writing has led to Brueggemann's works being highly valued by ministers / pastors / priests, theologians in other fields of specialisation, and the broader church public. This, in part, explains Brueggemann's sustained popularity, productivity, and influence.

Brueggemann's Spirituality of the Psalms (2002) is a popular work in the sense that it is a booklet written with no academic purposes in mind?. However, it has strong academic precursors in earlier publications by Brueggemann - cf. Brueggemann 1980:3032, 1982, 1988, 1991, 1995, and most notably, Brueggemann 1984.

$6 \quad$ Craghan here refers to Brueggemann (1980:3-32), the direct precursor to Brueggemann (1984) and, thus; Brueggemann (2002) - see below.

7 This booklet is however not meant for uneducated readers, as scattered reference to leading lights in the fields of sociology, philosophy and psychology (cf. Brueggemann 2002:ix, 14, 42 respectively) would indicate. 
The latter work, The Message of the Psalms, was adapted (cf. Ballard 2002/2003), with individual Psalm discussions now omitted, to become Spirituality of the Psalms. Here, as there (Brueggemann 1984:25-167), a three-part analytical framework is used with which to categorise the Psalms, and human life, as reflecting orientation, disorientation, and new orientation (Brueggemann 2002:viii, x, 813). He relates this to the work of God in Christ ("crucifixion and resurrection") in a paradigmatic way, as a Christian - though not a Christological - interpretative strategy (Brueggemann 2002:x, 1213). In the church this crucifixion-resurrection pattern is reflected in the ritual of baptism, and in the Old Testament in the history of Jerusalem and the exile, as a pattern of "loss" and "gift" (Brueggemann 2002:xi). In modern life, Brueggemann (2002:xiixiii, 14-15, 26) seeks in this way to counter the relentless optimism that Western / American popular culture demands of its subjects. What is more, the orientation-disorientation-new orientation interpretative matrix Brueggemann adopts, is a dialogical exegetical approach, that is: sensitive to the internal debate of the Psalms, and dynamic, that is: sensitive to the movement in people's lives from one circumstance to the other.

The value of the Psalms, reflects Brueggemann (2002:1-2), lies in the breadth of experience they give voice to, both in ancient Israel and for later believers. The problems of modern writings on the Psalms are that devotionals are often pious but naïve, whereas scholarship frequently offer academic understanding without being "belief-full” (Brueggemann 2002:7) perception. Rather, Brueggemann (2002:2-5) would have it, scholarship and discipleship should enrich one another. Gunkel (1926, 1933), Mowinckel (1922-1924, 1962) and Westermann (1977) must meet the soul (Brueggemann 2002:3-7). This requires what Brueggemann terms "a postcritical reading of the Psalms” (Brueggemann 2002:7; cf. 3), for which Paul Ricoeur's "second naivité" (cf. Schneiders 1985:19) would perhaps be a more generally recognisable term.

The Psalms of orientation, as the first part of Brueggemann's analytical framework, reflect stability in the relationship between those praying and God (Brueggemann 2002:16-24). God's acts of creation and maintenance offer theological and social certainties, and these Psalms both reflect and create that reality liturgically. These Psalms hence reflect the values of a powerful social class, and may for them serve purposes of dominance. For those dominated, these 
Psalms may however express hope, even eschatological expectations. Four kinds of Psalms fall into this orientation dimension: creation (Pss 8, 33, 104, 145), Torah (Pss 1, 15, 19, 24, 119), wisdom (Pss 14, 37) and well-being (Pss 131, 133) Psalms.

In the Psalms of disorientation (Brueggemann 2002:24-45), active faith within negative circumstances is found. Realism in facing the world as it is meet with belief in God despite the circumstances. This is not pop theology, civil religion, nor even the church's spirituality. Here, God does change, as do the circumstances of life. Yet, trust in God remains: it is indeed Yahweh that is spoken to, even if in derogatory or disrespectful ways. Surprisingly, positive sentiments (assurance of relief) are often reflected here too. Psalms of disorientation may be personal (Pss 13, 35, 86) or communal (Pss 74, 79, 137).

A new orientation is found in Psalms 30, 34, 40, 138 (on personal thanksgiving), 65, 66, 124, 129 (on communal thanksgiving), 29, 47, 93, 97, 98, 99, 114 (on kingship), and 100, 103, 113, 117, 135, 146-150 (on praise). These are characterised by unexpected grace by God, and a new well-being, nurtured through the previous difficulties (Brueggemann 2002:46-57).

This three-in-one spirituality Brueggemann finds reflected in the Psalms is certainly true to life; hence the enduring influence of the Psalms. Interesting is Brueggemann's greater emphasis on the second dimension, disorientation, as is his continued interest in the use of the Psalms for social justice in the last section of the publication (Brueggemann 2002:58-69). This indicates where lies for him the spiritual centre of the Psalms: theodicy. The Psalms, and Christianity, are not only individualistic. Justice mediates communion, which implies fairness before God. In the Psalms, theodicy is not only a question of God's love versus God's power (i.e. against evil), but - drawing on Thomas Merton and José Miranda - also a social concern: who is in power in such a way as to define legal, economic and political balances, and present these as the will of God? Theodicy thus combines religion and society within revolution, in latter-day societies as well as in the Psalmic language: of the wicked and righteous, and of God's just sovereignty. Hence, both sociologically and in the Psalms, either an unacceptable system and its legitimating God may be rejected, or God is called on to sabotage the unacceptable social system. 
Thus, Brueggemann (2002:69-74) indicates, a spirituality of orientation will in essence be pro status quo; a spirituality of disorientation will tend to be revolutionary; and a spirituality of new orientation will seek to construct a new consensus. The Psalms are therefore historically contingent, and cannot be read uncontextually, without social relevance ${ }^{8}$. Praying the Psalms is at once an act of committed faith and an act of critical justice.

\section{WAAIJMAN'S SPIRITUALITY AND THEOLOGY OF THE PSALMS}

Kees Waaijman, Carmelite priest, director of the Titus Brandsma Instituut and professor of Spirituality at Radboud Universiteit (until recently called the Katholieke Universiteit Nijmegen) is, no doubt, the foremost figure in Spirituality scholarship internationally, with his Spiritualiteit: Vormen, grondslagen, methoden (2000) the most comprehensive resource in the field. After some four decades working on Spirituality and as a Psalms specialist (cf. Waaijman 1980, 1981, 1983, 1989), he offers his readers a depth of insight into biblical, historical and contemporary spirituality. The same is the case again here in Mystiek in de psalmen (2004), though it is an altogether different kind of work to Waaijman 2000. Where in the 2000-publication he wrote about spirituality, in the 2004-work, Waaijman writes spirituality. Perhaps this is why he personally regards the new volume as his crowning work.

Similar to much of his other writings, the approach in Waaijman 2004 is what may be termed "thematic" or "idea-logical": one after another, certain topics from the history and practice of religion / philosophy / spirituality are selected and explicated. The progression in the argument does not follow a hard, step-by-step logic, but rather certain ideas imply others, in a variety of ways, with the progression of thought driven by texts and themes from within the interdisciplinary field that is Spirituality. Though such a writing style may lead to a thoroughly philosophically oriented spirituality, Waaijman's exegetical grounding (he frequently refers to standard exegetical works such as Zenger 2003 and Westermann 1983; cf. e.g. Waaijman 2004:9, 21) prevents this, and renders this a biblical

8 “... the spirituality of the Psalms is shaped, defined and characterised in specific historical, experiential categories and shuns universals" Brueggemann (2002:73). 
spirituality. In addition, Waaijman has a linguistic register which gives him access to wide-ranging written spirituality sources, which he draws on extensively. Clearly, he is also the most versed of the authors under discussion here in the classic literature of Spirituality. Interestingly, apart form his direct subject matter here, the Psalms, the most influential other source on Waaijman's thinking are the writings of Martin Buber (cf. Waaijman 1976, 1990).

Waaijman (2004:10) seeks in this publication to deduce from his study of the Psalms the contours of the mystery of God ("godsmystiek"). The Psalms' mystic language covers a range of possibilities (Waaijman 2004:10-12). Dominant, though, is "the Name" through which, in prayer, humanity and divinity meet (Waaijman 2004:13-14) ${ }^{9}$, and which therefore becomes a repetitive theme throughout Waaijman 2004. To signify God, Waaijman mostly utilises the term "Wezer" - "He who is / That which is", among other connotations -, a term loaded with both biblical-revelatory and existential-philosophical connotations.

Among the three mystical starting points - the self, the other, and the Other - it is the latter which defines the former two (Waaijman 2004:14-16). This happens in concrete contexts (Waaijman 2004:16-18), through a dialogical immediacy ("dialogische onmiddelijkheid" - Waaijman 2004:18) which elicits respons-ability ("antwoordelikheid" / "responsibilité" - Waaijman 2004:19), that is, giving oneself over in trust, resulting in creative re-formation (Waaijman 2004:19-20). In this sense, the Psalms are mystically dialogical ${ }^{10}$.

With wide-ranging references to Christian, Jewish and Muslim mystics and to Scripture, the latter with the most detailed focus on sections from the Psalms, Waaijman discusses a variety of topics in spirituality. These are: creation (Waaijman 2004:21-31), being saved from death (Waaijman 2004:32-42), forgiveness and re-creation (Waaijman 2004:43-54), fear, trust and meeting God anew (Waaijman 2004:55-67), one's own life's journey (Waaijman 2004:

9 Cf. Snyman's (1997:377-378) take on the Name.

10 Wölber (1976:727), drawing on Küng (1974), makes the point that the Bible is not only a book that talks about God, but also with God - an insight which is also full of dialogical possibilities (cf. Bezuidenhout 1995:713-714, 718). 
68-78), respect for / fear of the Lord (Waaijman 2004:79-89), good and evil (Waaijman 2004:90-100, 101-111), God's Name, interestingly connected with liberation (Waaijman 2004:112-123), God and Israel (Waaijman 2004:124-134), God as king (Waaijman 2004:135146, 147-157), pilgrimage (Waaijman 2004:158-168), Torah / (wisdom) teaching (Waaijman 2004:169-179), justice and protection (Waaijman 2004:180-190), and life and death (Waaijman 2004:191).

Frequent descriptions of real-life experiences affecting all people (e.g. Waaijman 2004:34-42) prevent this spirituality from becoming esoteric, as do many Hebrew word analyses (e.g. Waaijman 2004:68), along with indications of historical dating and events (e.g. Waaijman 2004:135-157). Universal human life circumstances form the backdrop to which Psalm sections are analysed. In addition, traditional theological themes such as sin and redemption (e.g. Waaijman 2004:43-54) also find their place.

In this way, Waaijman is in essence writing theology - a theology of the Psalms, to be sure, but something quite different to the tradition that has developed within Old Testament science with the sub-genre of scholarship called Old Testament Theology (cf. Ollenburger, Martens \& Hasel 1992; Adam 2004:42-44). The differences lie not only in the deliberately more restricted subject matter, namely with the focus on the Psalms, but also in the span of sources drawn on. These are not exclusively Christian, but are selected in order to place certain aspects or verses from a psalm within a wider, more illuminating framework. This results in an outcome that is sensitively inter-religious Christian theology-in-themaking, and as such may be of great interest also to scholars in the fields of missiology, science of religion, and inter-religious dialogue.

It must be noted, though, that reading this book will be an intellectually more profitable exercise if one has read some of Waaijman's other works. His reference to the soul ("ziel" Waaijman 2004:28-30), for instance, becomes more lucid if one has read an earlier explication of his (e.g. Waaijman 1996:5-19) on this term.

\section{THE WAY IN WHICH FIRTH HEARS THE LORD}

The contribution by Firth (2005a), a Baptist who teaches Old Testament at Cliff College in the UK is introduced with a theoretical orientation which explains his approach to the Psalms. Apart from placing the Psalms centrally in his own faith development (the 
Psalms are also central to his academic life - see Firth 1996, 2001:19, 2005b) and that of his faith community (Firth 2005a:1-3), Firth in addition places his reading of the Psalms within the research history on these texts (Firth 2005a:4-13). In broad outlines, he sketches the development of Psalm studies from the traditional phase (where Davidic authorship is more or less accepted), to the historical-critical and therefore cult-oriented phase (with Gunkel 1926, 1933 and Mowinckel 1922-1924, 1962 most influential), to the latest, that is, literary-oriented phase. Firth argues that the latter approach is the most productive, exegetically, because it replaces the uncertainties of historical reconstructions with the greater certainties of thematiccompositional activities of the Psalms' compilers, and spiritually, because it holds the greatest promise for modern-day application. In practice, though, Firth is not averse to considering historical possibilities (e.g. Firth 2005a:24, 56, 74).

Firth credits Brueggemann as the leading light of this literaryoriented approach, and draws strongly on the latter's orientationdisorientation-reorientation matrix of Psalm analysis, noted above, but renames them as order, disorder, and reorder. However, Firth (2005a:11, 101-122, 128) adds greater emphasis to the Royal Psalms than Brueggemann does (cf. Brueggemann 2002:x), because he takes as his primary binary stance the cooperative distinction between pain and praise one encounters in the Psalms (Firth 2005a:3), which translates as experience and eschatology in the Royal Psalms (Firth 2005a:11, 128).

The Psalms of the ordered world, with which Firth (2005a:1538) starts his analysis, reflects God's nature as orderly, which thus characterises creation, to which the faithful should orient their lives in prayer (Firth 2005a:17-24). The Torah Psalms (1, 19, 119) and those that invite entering the community of faith (Psalms 15 and 24) are, within this scheme, complementary, combining respectively the internal and the external; alternatively: the individual and the context. A faith ordered to God's presence will seek to impart that presence to the world, since creation is ordered - something Psalms 8 and 147-148 celebrate (Firth 2005a:24-27), and which the Psalms both praise and trust in (respectively, Pss 29, 93, 104, 146 and 46, 23, 121; Firth 2005a:29-38).

The Psalms of the disordered world reflect the negative experiences of life (Firth 2005a:39-42). Individual penitence (Psalm 
51) and communal confession (Psalms 90 and 106) seek the cause for this disorder within; external sources of pain threaten, again, a single believer (Pss 7, 139, 3, 56, 69) or the group (Psalm 79; Firth 2005a:49-65). At times, God creates the disorder, either through punishment or absence - Psalms 6 and 88, relating to the individual, and 60 and 83, relating to the communal (Firth 2005a:65-77).

In the Psalms of the reordered world, God answers prayers, indicating Divine reign, and resulting in testimonies and thanksgiving for particular acts, which in turn elicit encouragement and undertakings (Firth 2005a:79-82). Thus, the individual experiences forgiveness (Psalm 32), healing (Psalm 30) and deliverance (Pss 92 \& 138), along with a renewed relationship with God (Psalm 73), which also relates to the community (Psalm 124; Firth 2005a:82-99).

Firth's discussion of the different Psalms are characterised by brief analyses of the contents of each text, divided into pericopes (which parallels the approach in Brueggemann 1984). Interwoven throughout the discussion of the Psalms, Firth remarks on the question his order-disorder-reorder matrix naturally raises, namely theodicy ${ }^{11}$. The problem of the goodness of God versus the evil experienced in life, touched on in many Psalms, and a central question of the human spirit (if not universally, then at least in all thought influenced by ancient Greek philosophy), is remarked on frequently and sensitively. The difficult questions are not shirked from, nor are the easy answers accommodated. It is in this thread of discussion which runs throughout Firth's tri-partite matrix, that the title of this book finds, to my mind, its major justification. Further justification is however found in the perspectives offered subse-

11 Firth (2005a:127) himself, reacting to the closing chapter of Brueggemann 1984, is ill at ease with applying the term "theodicy" to the Psalms. He argues that, taken as a whole, the Psalms already know the "reordering" / hope (so too Brueggemann 2002:xii), and hence the negative view implicit in the term "theodicy" is inappropriate for use relating to the Psalms. This fits well with the view Firth expresses repeatedly, that even when experiencing the "disorder", the faithful already have hope, since they have experience of the "order". This is a valid and valuable theological and pastoral argument. However, if one defines the term "theodicy" slightly broader, as I do here - "the problem of the goodness of God versus the evil experienced in life" - it too contains this positive element, and thus remains a handy shorthand-term to describe this involved matter. 
quently on how this philosophical-theological issue, theodicy, relates to prayer (Firth 2005a:101-129).

On the Royal Psalms, Firth (2005a:101-105) argues as follows: these Psalms gain in the post-exilic period of Israel's history messianic connotations, namely as prayers of hope for the future, based on what had been in the past. The New Testament employs the Psalms in the same way, Firth indicates, expecting God's kingdom yet to arrive in its fullness. The scheme of order-disorder-reorderhope is then used by Firth (2005a:105-120) with reference to Psalms 2, 89, 132, 20, 67 and 117, to demonstrate this manner of praying. In this and other ways, therefore, the Psalms may be said to shape the prayers of the faithful, whichever kinds of prayers are prayed. Past and future shape our present spirituality (Firth 2005a:127-129). Firth's (2005a:12) stress on the close relationship between individuality and communality in the Psalms, in contra-distinction to the individualism characteristic of our times, thus fits well into this argument.

\section{TAKEN TOGETHER}

These four books contribute, no doubt, to breaking the relative silence on Biblical Spirituality (cf. Adam 2004:15). This is the more so because, taken together, these four works show some appealing parallels, but also some notable differences.

Interestingly, none of these books are fully academic books, in the sense that one would expect from a scholarly monograph. At the same time, none is "unacademic": an informed reader can see between the lines the exegetical work, the theories and the authors underpinning what is being said. This approach, combined with, in all four works, the simplicity of style, render them all valuable educational tools.

More foundationally, all four the publications taken in review here stress the communal aspect of spirituality: the Christian faith has a social conscience. However, the way in which this point is driven home, differs in noticeable ways. The liberal ${ }^{12}$ Presbyterian Brueggemann draws on social-scientific theory with which to

12 "Liberal" should not be understood here in the classical sense, of the rationalist and moralist exegesis of for instance 19th century Europe, but in the sense in which it is employed in American politics, which is mirrored heavily in the fault lines of the American ecclesial geography. 
analyse both biblical text and modern context; the Catholic exegete Stuhlmueller enriches biblical text by thick referencing to other biblical texts, thus building a directly Bible-based case; the Catholic spiritualist Waaijman draws on existential thought to place ordinary aspects of life in a wider, faith-full dimension; the Baptist former missionary Old Testament scholar Firth draws on vignettes from his personal experience to demonstrate the concreteness of psalmic contextual spirituality. In this way we find ourselves presented with a prism of possibilities, each deeply felt and with solid academic and philosophical integrity. Here too, it seems, then, my earlier points (Lombaard 2005:147-148) remain applicable: that one always tends to find one's own spirituality back in Scripture, not by design, but as an inescapable matter of an individual's frame of reference, and, thus, that spirituality is always intensely personal. These distinctive faith configurations are, however, strongly communally formed - the natural influences of faith and life that (in)forms each person's own faith and life. It is, furthermore, precisely this collection of personal pieties that, we find, enriches and (in)forms one another in various ways, rendering spirituality thus, in a circular way, at the very same time again inescapably communal.

That said, though, the differing text-theoretical / hermeneutical / exegetical approaches must be noted. It is on this point that a critical evaluation must be offered, in the hope that it will stimulate debate and lead to clarity on the different approaches. It is Firth in particular who offers us with his opening methodological pages a strong stimulus to consider not only what is being done in Biblical Spirituality, but also how it is done ${ }^{13}$.

For one, to state that investigating the editorial linkages between the units of this literary body is a literary process, and not a historic one, does not take into account that these editorial processes took place in very specific historical circumstances. The editors had

13 Firth is, of course, correct in that he finds himself part of the new wave in Psalm research, which seeks out the links between the different units (Psalms / Psalm collections / Psalm genres) within this literary body, and posits for these theological intent in the compositional process. However, as is the case with all a-historical approaches (cf. Lombaard 2005/2006), this line of reasoning errs, in my view, in two ways: it overstates its own possibilities, and it understates the possibilities of the historical approaches against which it mirrors itself. 
a point to make, and as with all writings, these points were made in the face of concrete circumstances. To ignore the For one, to state that investigating the editorial linkages between the units of this literary body is a literary process, and not a historic one, does not take into account that these editorial processes took place in very specific historical circumstances. The editors had a point to make, and as with all writings, these points were made in the face of concrete circumstances. To ignore the contextuality of editorial work is to ignore a vital aspect of this communicative process (cf. De Villiers 1999:432).

In practice, though, Firth (2005a:103) does indicate a firm dating for such editorial activities, viz. post-exilic. It is precisely because certain Psalms are late compositions, drawing on earlier traditions, argues Stuhlmueller (2002:68-70) that they are useful today. The relationship between the text-as-literature approach and the historical approach remains, always, more than a little unclear.

Second, all literary interpretations of whichever texts are uncertain, and often reflect much of the analysts' own concerns (cf. Lombaard 2005:139-150). Naturally, this does not make such interpretations invalid; it is very difficult to prove, though, that these interpretations existed within the texts themselves - as difficult as proving the cultic or historical background to an individual Psalm to which the a-historical approaches object. The nigh impossibility of certainty of interpretation is thus not escaped by the new wave of Psalm interpretations. The focus may have shifted to the body of Psalms as a whole, rather than the individual Psalms, and as such it constitutes a valuable contribution; however, the results are no less uncertain. They remain reconstructions; the hermeneutical circle à la Schleiermacher (cf. Knierim 1995:269) still applies as much with one exegetical approach as with the other.

This is not meant as a criticism of either historical or literary approaches to the text of the Old Testament in general and the Psalms in particular. This is a remark from philosophy of science. It has long been accepted that the choice for rationalism is of itself irrational; in more modern times, this climaxed in the insight that method does not bring us scientific truth (Gadamer 1975). Scholarship, that is, intellectually satisfying interaction with one's subject matter (Lombaard 2005:7-9), is in itself an ideal. What is more, it is at once highly individualistic and a thoroughly social 
process. The fact that it is the texts of the Bible which we have chosen as our subject matter, is a choice already deeply rooted in spirituality, which finds its roots in the Old Testament itself.

See (Knierim 1995:269-297) for an attempt to deduce the meaning of spirituality within the Old Testament, coloured, though, as it is by his structuralist approach reading biblical texts. This approach is ill-suited to teasing out spiritualities which are thoroughly contextually, that is, historically conditioned. Harper 2000: 311-326, too briefly to be successful, employs a thematic approach.

The three-fold matrix employed by Brueggemann and Firth also invites further comment. With both authors, their use of this interpretative matrix is meant at least in part as a reaction against unsophisticated popular impressions of the Psalms, namely as songs of praise only. The middle dimension of their matrix highlights the negative. This is, I would suggest, apt: it is in the most negative of circumstances where faith becomes most concrete. The kinds of biblical spirituality (cf. Endres 2002:147-149) cannot be restricted, though, since the ways of the Spirit cannot be defined (Wölber 1976:725). At the same time, this highlighting of the middle dimension of their matrix by Brueggemann and Firth is intended to subvert the one-sided "power of positive thinking" ${ }^{14}$-culture of our times. Positively, the stress that God's presence must be noted within the negative experiences of life, must be lauded. It adds a depth to popular theology that is much needed. With the works by Stuhlmueller and Waaijman, such a "social intent" with the writing of their works is less overt, partly due to their interpretative frame not being made clear as directly. Still, they make much the same point in different, less paradigmatic, ways. This more subtle approach indicates again the variety of ways in which the intent of a book may be reached.

\section{CONCLUSION}

Quite naturally, the Scriptures form an integral part of Christian spirituality (Kourie 2002:14-18; Claassen 2003:115). Two matters should be kept in mind in relation to this, though: first, that the

14 This term had been popularised by the title of the book by Peale (1952), with its success being attributable both to playing to the American cultural "can do"-milieu and the success theology as an integral part of that milieu. 
ancient spiritual experiences we encounter in the Bible were human incidents (cf. Craghan 1983:xii, 1), but, second, that they were, theologically speaking, not only brought about by humans. Hence, the Bible itself is a spiritual occurrence. Biblical spirituality thus implies a life of faith that draws daily on the Bible ${ }^{15}$ - this holds true both for individuals and the church (Wölber 1976:725). The Word of God itself acknowledges in its pages different forms of spirituality (so e.g. Harper 2000:312). This we see here again, with these four books taken in review. The spirituality of the Psalms combines for all four authors exegesis and faith, that is, giving bread and not just stones (Claassen 2003:13; cf. Wölber 1976:725).

Though faith may at times be described as simple, simplicity should not be expected to characterise this hermeneutical process. The complexity of the texts of the Bible, as texts (cf. e.g. Deist 1988) ${ }^{16}$, and hermeneutically (cf. foundationally, Thiselton 1992 and as a case study, Deist 1994), is well established. Equally, the spirituality of the modern Bible reader is situated within an involved, complex contextuality (cf. Dantine 1976:591-593; Claassen 2003:137-145). The fact remains that the way in which Scripture is read, directly affects the lives of faith of those readers (cf. e.g. Claassen 2003:57-63, 115-127; Adam 2004:19). This is one of the reasons that Biblical Spirituality is such an important field of study, combining as it does scientific exegesis with the "more" (cf. the opening paragraph of this paper) of critical faith interaction.

It is a little strange, though, that when reference is made to Spirituality and the Old Testament, it is almost by definition the Psalms that are mentioned (cf. Custer 1994:160; De Villiers 1999:419-422; Sipkema \& Lelyveld 2000:132). This is nothing new, as the following statement by Sorg (1948:535, cf. 537), drawing on St. Basil, shows: "While the whole of the Bible is inspired, yet it may truly be said that the subject-matter of the psalms excels in spirituality". The question must be asked: why would this be so? Has, perhaps, liturgical tradition, often based on Christological Psalm exposition, along with the relative brevity of the Psalm texts

15 The distinction by Sorg (1948:529-533) between objective and subjective spirituality of the Psalms, that is, respectively, between the faith we find reflected in the Bible and the faith of the latter-day believer (in)formed by the Bible, deserves to be taken up and developed further.

16 And as Craghan (1983:vii) exclaims: “The text is the thing!”... 
determined this? The rest of the Old Testament certainly offers much more than is, for a variety of reasons (cf. Lombaard 2003:433-450), expected from it, even on the "driest" parts of the Old Testament library, such as the genealogies (cf. Lombaard 2006:146-164).

\section{Consulted literature}

Adam, P 2004. Hearing God's words. Exploring biblical spirituality (New Studies in Biblical Theology 16). Downers Grove: InterVarsity Press.

Ballard, H W 2002/2003. Review: Walter Brueggemann, Spirituality of the Psalms. Journal of Hebrew Scriptures 4 (2002-2003), www.arts.ualberta.ca/ JHS/reviews/review050.htm.

Bezuidenhout, L C 1995. Perspektiewe uit die Psalms wat lig werp op die wese van die geloofsgemeenskap. HTS Teologiese Studies 51/3, 712-719.

Brueggemann, W 1980. Psalms and the life of faith: a suggested typology of function. Journal for the Study of the Old Testament 17, 3-32.

-, 1982a. Genesis. A Bible commentary for teaching and preaching (Interpretation).

-, 1982b. Praying the Psalms. Winoa: St Mary's Press.

-, 1984. The message of the Psalms. A theological commentary. Minneapolis: Augsburg Publishing.

-, 1988. Israel's praise. Doxology against idolatry and ideology. Philadelphia: Fortress Press.

-, 1991. Abiding astonishment: Psalms, modernity and the making of history (Literary Currents in Biblical Interpretation). Louisville: Westminster John Knox Press.

-, 1995. The Psalms and the life of faith. Minneapolis : Fortress Press.

-, 1997. Theology of the Old Testament: testimony, dispute, advocacy. Minneapolis: Fortress Press.

-, 2002. Spirituality of the Psalms. Minneapolis: Fortress Press.

Claassen, J T 2003. Christelike spiritualiteit as kommunikatiewe handeling (MTh-verhandeling). Pretoria: Unisa.

Craghan, J F 1983. Love and thunder. A spirituality of the Old Testament. Collegeville: The Order of St. Benedict, Inc.

Custer, J S 1994. The Old Testament. A Byzantine perspective. Pittsburgh: God With Us Publications.

Dantine, W 1976. Phantasie zum Aufbruch aus dem Gewohnten. Spiritualität und geschichtliches Handeln. Evangelische Kommentare 9/10, 591-593.

Deist, F E 1988. Witnesses to the Old Testament (The Literature of the Old Testament, Volume 5). Pretoria: NG Kerkboekhandel. 
-, 1994. Ervaring, rede en metode in Skrifuitleg. 'n Wetenskapshistoriese ondersoek na Skrifuitleg in die Ned. Geref. Kerk 1840-1990. Pretoria: Raad vir Geesteswetenskaplike Navorsing.

De Vaux, R 1961. Ancient Israel. Its life and institutions. (Translated by J McHugh). London: Darton, Longman \& Todd.

De Villiers, P 1999. The Psalms and spirituality. Old Testament Essays 12/3, 416-439.

Endres, J C 2002. Psalms and spirituality in the $21^{\text {st }}$ century. Interpretation 56, 143-154.

Firth, D G 1996. Responses to violence in Lament Psalms of the individual (PhD disseration). Pretoria: University of Pretoria.

-, 2001. Stages of prayer through the Psalms, South African Baptist Journal of Theology 10, 1-9.

-, 2005a. Hear, o Lord. A spirituality of the Psalms (Cliff College Academic Series). Calver: Cliff College Publishing.

-, 2005b. Surrendering retribution in the Psalms: responses to violence in the individual complaints (Paternoster Biblical Monographs-PBM). Carlisle: Paternoster.

Gadamer, H-G 1975. Wahrheit und Methode: Grundzüge einer philosophischen Hermeneutik. Tubingen: Mohr.

Grimm, G 1977. Rezeptionsgeschichte. Grundlegung einer Theorie. München: Wilhelm Fink.

Gunkel, G 19264․ Die Psalmen (HAT, II.2). Göttingen: Vandenhoeck \& Ruprecht.

Gunkel, G \& Begrich, J 1933. Einleitung in die Psalmen: Die Gattungen der religiosen Lyrik Israels (Göttinger Handkommentar zum alten Testament, 2). Göttingen: Vandenhoeck \& Ruprecht.

Harper, J S 2000. Old Testament spirituality, in: Collins, KJ, (ed.) Exploring Christian spirituality. An ecumenical reader. Grand Rapids: Baker Book House, 311-326.

Knierim, R P 1995. The task of Old Testament theology. Substance, method, and cases. Grand Rapids: William B. Eerdmans Publishing Company.

Kourie, C 2002. What is Christian spirituality?, in: Kourie, C \& Kretzschmar, L (eds). Christian spirituality in South Africa. Pietermaritzburg: Cluster Publications, 7-33.

Kuhn, T 1970. The structure of scientific revolutions (2nd ed.). Chicago: University of Chicago Press.

Küng, H 1974. Christ sein. München: R. Piper.

Lombaard, C 2003. The Old Testament in Christian spirituality: perspectives on the undervaluation of the Old Testament in Christian spirituality. HTS Theological Studies 59/2, Junie 2003, 433-450. 
-, 2005a. South African perspectives on the communication of the Bible in church and society ( $\mathrm{PhD}$ dissertation). Potchefstroom: North-West University, Potchefstroom campus

-, 2005b. Four South Africans' proposals for a central theme to "Scriptural spirituality”. Scriptura 88/1, 139-150.

-, 2005/2006. The Old Testament between diachrony and synchrony: two reasons for favouring the former. Paper read at the ProPent (Project for the Study of the Pentateuch) conference, 27-29 August 2005, at the Hammanskraal conference centre of the University of Pretoria. To be published in a 2006 edition of the Journal for Semitics.

-, 2006. Genealogies and spiritualities in Genesis 4:17-22, 4:25-26, 5:1-32, in: De Villiers, P.G.R., Kourie, C.E.T. \& Lombaard, C. (eds.) The Spirit that moves. Orientation and issues in spirituality (Acta Theologia Supplementum 8). Bloemfontein: University of the Free State, 146-164.

Mowinckel, S 1922-1924. Psalmenstudien, I VI. Kristiania: J. Dybwad.

-, 1962. The Psalms in Israel's Worship. Oxford: Blackwell.

Nowell, I 2003. Review: The spirituality of the Psalms. By Carrol Stuhlmueller. Worship 77/5, 479-480.

Ollenburger, B C, Martens, E A \& Hasel, G F (eds) 1992. The flowering of Old Testament theology. A reader in twentieth-century Old Testament theology, 1930-1990 (Surveys in Biblical and Theological Study 1). Winona Lake: Eisenbrauns.

Peale, N V 1952. The power of positive thinking. New York: Simon \& Schuster Adult Publishing.

Schneiders, S M 1985. Scripture and spirituality, in: McGinn, B, Meyendorff, J \& Leclerq, J (eds) Christian spirituality: origins to the twelfth century. London: SCM Press, 1-20.

Sipkema, E \& Lelyveld, K 2000. De Regel van de H. Benedictus en het gebruik van de Psalmen. Een spiritualiteit van de Psalmen. Amsterdamse cahiers voor exegese van de Bijbel en zijn tradities 18, 131-138.

Snyman, F 1997. Spiritualiteit - 'n perspektief uit die Ou Testament. In die Skriflig 31/4, 375-387.

Sorg, R 1948. The spirituality of the Psalms. Orate Fratres XXII/12 (Oct. 21, 1948), 529-541.

Stuhlmueller, C 1983. Psalms 1 and 2. (Message of Biblical Theology series; Old Testament Message 21 and 22). Wilmington: Michael Glazier.

-, 2002. The spirituality of the Psalms. Collegeville, Minnesota: Liturgical Press.

Thiselton, A C 1992: New horizons in hermeneutics. Grand Rapids: Zondervan Publishing House. 
Von Rad, G 1962. Theologie des Alten Testaments, Band 1: Die Theologie der geschichtlichen Überlieferungen Israels (Fünfte, durchgesehen Auflage). München: Chr. Kaiser Verlag.

Waaijman, C J 1976. De mystiek van ik en jij - een nieuwe vertaling van "Ich und $\mathrm{Du}$ " van Martin Buber met inleiding en uitleg en een doordenking van het systeem dat eraan ten grondslag ligt (Proefschrift, Katholieke Universiteit Nijmegen). Utrecht: Bijleveld.

Waaijman, K 1980. Psalmen over recht en onrecht : Psalmen 3, 4, 5, 7, 11, 17, 23, 26, 27, 57, 63. Kampen: J.H. Kok.

-, 1981. Psalmen by ziekte en genezing. Kampen: J.H. Kok.

-, 1983. Psalmen over de uittocht : het lied van Mirjam, het lied van Mozes, Psalmen 66, 68, 77, 78, 80, 81, 95, 105, 106, 114, 135. Kampen: J.H. Kok.

-, 1989. Psalmen over de schepping : psalmen 8, 29, 33, 65, 74, 104, 136, 139, 147, 148. Kampen: J.H. Kok.

-, 1990. De mystiek van ik en jij. Een nieuwe vertaling van "Ich und du" van Martin Buber. Kampen, J.H. Kok.

-, 1996. The soul as spiritual core concept. Spiritus 6, 5-19.

-, 2000. Spiritualiteit: vormen, grondslagen, patronen. Gent: Carmelitana.

-, 2004. Mystiek in de psalmen (Serie Mystieke Teksten en Thema's, 22). Baarn: Uitgeverij Ten Have.

Westermann, C 1977. Lob und Klage in den Psalmen (5., erw. Aufl). Göttingen: Vandenhoeck und Ruprecht.

-, 1983 ${ }^{3}$. Genesis 1-11 (Biblischer Kommentar Altes Testament 1/1). Neukirchen-Vluyn: Neukirchener Verlag.

Wölber, H-O 1976. Der Königsweg der Spiritualität. Gedanken zur Frömmigkeit aus der Bibel. Evangelische Kommentare 9/12, 724-727.

Zenger, E 2003. Psalmen Auslegungen, I. Freiburg: Herder. 